Check for updates

Cite this: RSC Adv., 2019, 9, 8204

Received 14th January 2019

DOI: $10.1039 / \mathrm{c} 9 \mathrm{ra00320 \textrm {g }}$

rsc.li/rsc-advances
Accepted 12th February 2019

\section{Catalytic ozonation process using a MgO nano- catalyst to degrade methotrexate from aqueous solutions and cytotoxicity studies in human lung epithelial cells (A549) after treatment}

\author{
Abdolazim Alinejad, ${ }^{\text {ab }}$ Hamed Akbari, ${ }^{a}$ Mansour Ghaderpoori, ${ }^{c}$ Ali Khani Jeihoonib \\ and Amir Adibzadeh (iD *a
}

Pharmaceutical compounds which enter the environment are classified as emerging pollutants. Among different drug compounds, anti-cancer drugs like methotrexate are of more concern due to their mutagenic, carcinogenic, and genotoxic properties. Therefore, the main objective of this study was to use catalytic ozonation processes (COPs) as novel advanced oxidation processes to degrade methotrexate from aqueous solutions. The calcination method was used to obtain a nitrate magnesium oxide nano-catalyst. The main variables considering the effect of single ozonation processes (SOPs) and COPs on the target pollutant were initial methotrexate concentration, contact time, solution $\mathrm{pH}$, and $\mathrm{MgO}$ dosage. The BET results indicated that the surface area of the $\mathrm{MgO}$ nano-catalyst was $140.031 \mathrm{~m}^{2}$ $\mathrm{g}^{-1}$. Based on the $\mathrm{BJH}$ plot, the size of the $\mathrm{MgO}$ nano-catalyst and average pore volume were $44.5 \mathrm{~nm}$ and $0.4454 \mathrm{~cm}^{3} \mathrm{~g}^{-1}$, respectively. The weight percent of $\mathrm{Mg}$ and $\mathrm{O}$ was $61.09 \%$ and $38.91 \%$, respectively. In acidic and alkaline $\mathrm{pH}$, the degradation rate of methotrexate showed a higher increase in SOPs and COPs than at neutral $\mathrm{pH}$. The degradation rate of methotrexate decreased with increasing concentration. By increasing the contact time, the degradation rate of methotrexate of both SOPs and COPs increased. Actually, the methotrexate degradation in COPs was faster than in SOPs. When using tert-butanol as a scavenger, the reduced removal efficiency in SOPs and COPs was $32 \%$ and $31 \%$, respectively.

\section{Introduction}

Drug or pharmaceutical compounds which enter the environment are classified as emerging pollutants. Recently, various studies have been reported on the presence of these compounds in surface waters and ground waters. ${ }^{1}$ Among different drug compounds, anti-cancer drugs are of more concern due to their mutagenic, carcinogenic, and genotoxic properties. Also, these compounds usually have low biodegradability. ${ }^{2}$ Methotrexate is one of the most important drugs used in chemotherapeutic applications. Methotrexate is an analogue of folic acid and can inhibit the enzyme dihydrofolate reductase. ${ }^{2,3}$ It is used in chemotherapy at both high and low doses in the treatment of some autoimmune diseases, such as rheumatoid arthritis, adult psoriasis, or ectopic pregnancy. ${ }^{4,5}$ Findings showed that with intravenous administration, more than $85 \%$ of the injected

${ }^{a}$ Health Research Center, Lifestyle Institute, Baqiyatallah University of Medical Sciences, Tehran, Iran. E-mail: rsr.adibzadeh@bmsu.ac.ir; Fax: +98-2182482483 ${ }^{b}$ Department of Public Health, Fasa University of Medical Sciences, Fasa, Iran ${ }^{c}$ Nutrition Health Research Center, Lorestan University of Medical Sciences, Khorramabad, Iran dose was excreted unchanged within 24 hours via the urine. ${ }^{6,7}$ As a result, it can enter municipal wastewater through hospital wastewater, ${ }^{8}$ and even concentrations of it in drinking water are detected. ${ }^{3,9}$ According to studies, methotrexate is partially eliminated by conventional wastewater treatment processes., ${ }^{\mathbf{4 1 0}}$ These drug compounds, depending on their concentration, can have different effects on human health. ${ }^{3}$ So far, various processes have been investigated to remove or degrade drug compounds from effluents. ${ }^{\mathbf{1 1 , 1 2}}$ Processes considered to remove methotrexate are $\mathrm{UV}-\mathrm{TiO}_{2},{ }^{13} \mathrm{UV}-\mathrm{H}_{2} \mathrm{O}_{2} / \mathrm{UV}-\mathrm{Fe}^{2+}-\mathrm{H}_{2} \mathrm{O}_{2} / \mathrm{UV}-\mathrm{TiO}_{2},{ }^{14}$ sonolysis-ozonolysis, ${ }^{\mathbf{1 5}}$ electro-synthesized ferrate(vI) ion, ${ }^{\mathbf{1 6}}$ and single ozonation processes (SOPs). ${ }^{3}$ As several studies have shown, advanced oxidation processes (AOPs) are some of the most important processes for the removal or the degradation of pharmaceutical compounds from various types of wastewater. ${ }^{17-19}$ AOPs are suitable processes for treating compounds that are refractory to biodegradation treatment like antibiotics. ${ }^{\mathbf{1 1 , 2 0}}$

One of the most important innovations in AOPs is the use of a solid as a catalyst: catalytic ozonation processes (COPs). Actually, SOPs have a relatively low efficiency in the degradation of refractory organic pollutants. The most important problems 
in SOPs are low solubility and low stability of $\mathrm{O}_{3}$ in water and slow reaction with some organic compounds. ${ }^{21}$ In COPs, the presence of metal oxides can increase the production of active radicals to degrade refractory compounds (eqn (1)-(3)): ${ }^{22}$

$$
\begin{gathered}
\mathrm{O}_{3}+[\mathrm{MgO}-\mathrm{S}] \Rightarrow\left[\mathrm{MgO}-\mathrm{S}^{\mathrm{O}_{3}}\right] \\
{\left[\mathrm{MgO}-\mathrm{S}^{\mathrm{O}_{3}}\right] \Rightarrow\left[\mathrm{MgO}-\mathrm{S}^{\circ}\right]+\mathrm{O}_{2}} \\
{\left[\mathrm{MgO}-\mathrm{S}^{\mathrm{O}^{*}}\right]+2 \mathrm{H}_{2} \mathrm{O}+\mathrm{O}_{3} \Rightarrow\left[\mathrm{MgO}-\mathrm{S}^{\cdot \mathrm{OH}}\right]+3 \cdot \mathrm{OH}+\mathrm{O}_{2}}
\end{gathered}
$$

The use of COPs eliminates or mitigates the disadvantages of SOPs. The advantages of COPs are a simple operation, low cost, proper mineralization, environment-friendly, non-toxic, highly stable, easy to produce, and short time. ${ }^{23}$ Due to high surface area and low recovery and production costs, metal oxides have a high potential for application in water and wastewater treatment. ${ }^{24}$ COPs represent a new technology for the removal or the degradation of organic pollutants in water and wastewater and include two process types: homogeneous and heterogeneous. Heterogeneous COP has attracted a great deal of attention recently due to its high efficiency in the degradation and mineralization of organic pollutants with low adverse effects. ${ }^{25}$ The heterogeneous COP is an attractive oxidation process which involves a solid catalyst in combination with $\mathrm{O}_{3}$ that can improve the efficiency of $\mathrm{O}_{3}$ in the breaking down of refractory organic compounds by radical reactions. ${ }^{26}$ A review of the literature suggests that the use of magnesium oxide $(\mathrm{MgO})$ as a catalyst is significantly associated with the ozonation process and has a useful effect on the degradation of pollutants that are refractory to biodegradation such as antibiotics. ${ }^{27,28}$ The catalyst is also widely used in conventional wastewater treatment, and for industrial and pharmaceutical sewages, dyes and phenolic materials. $\mathrm{MgO}$, due to its adsorption properties, is also a promising substance as an adsorbent. ${ }^{29} \mathrm{MgO}$ is a material with a wide application range. ${ }^{24} \mathrm{MgO}$ is heterogeneous which means it has high catalytic potential for the degradation of refractory pollutants, such as drugs. ${ }^{2328}$ The high-power degradation is one of the most important features of this catalyst. ${ }^{30} \mathrm{MgO}$ is a cheap catalyst with electromagnetic absorption characteristics at high wavelengths near those of visible light, and under sunlight in the range of 200 to $400 \mathrm{~nm}$ wavelength can be exhibit. MgO nano-catalysts exhibit their highest absorption in the wavelength range $385 \mathrm{~nm}$ to $360 \mathrm{~nm} \cdot{ }^{31,32}$ Metal oxides due to their high surface area and low recovery and production costs have a high potential for application in water and wastewater treatment. $\mathrm{MgO}$, among the large family of metal oxides, is a widely used material. ${ }^{24} \mathrm{MgO}$ is considered as one of the metallic semiconductors which degrade refractory compounds such as drugs by ultraviolet radiation, although it is applied to a lesser extent than $\mathrm{TiO}_{2}$. MgO has a bonded cavity $(2 / 3 \mathrm{eV})$ similar to $\mathrm{TiO}_{2} \cdot{ }^{31}$ Based on a literature review, so far, for different pollutants like dyes, formaldehyde, catechol, and VOCs, heterogeneous COPs has been used, but no reports have yet been published of the removal or degradation of methotrexate. For this reason, $\mathrm{MgO}$ has been selected as a solid catalyst for the removal or the degradation of methotrexate. Therefore, the main objective of this study was to use COPs as novel AOPs to degrade methotrexate from aqueous solutions.

\section{Experimental}

\section{Chemicals}

Chemicals needed in this research included methotrexate (purity > 99\%), magnesium nitrate $\left(\mathrm{Mg}\left(\mathrm{NO}_{3}\right)_{2}\right)$, sulfuric acid $\left(\mathrm{H}_{2} \mathrm{SO}_{4}\right)$, sodium hydroxide $(\mathrm{NaOH})$ and tert-butanol $\left(\mathrm{C}_{4} \mathrm{H}_{10} \mathrm{O}\right)$. All materials were obtained as high analytical grade from Merck and Sigma-Aldrich Chemicals Company.

\section{Preparation of $\mathrm{MgO}$ nano-catalyst and experimental procedures and analytical methods}

To prepare the magnesium oxide nano-catalyst $(\mathrm{MgO})$, the procedure of Moussavi et al. ${ }^{\mathbf{3 0}}$ was used. In this procedure, the calcination method was used to obtain nitrate magnesium oxide nano-catalyst. In this way, MgO was obtained from natural mineral magnesite from Iran. Initially, magnesium ore became fine particles by crushing. After the initial crushing, the crushed particles were washed with distilled water and then dried. To eliminate impurities in the crushed particles, they were placed in an acid solution for $5 \mathrm{~h}$. After soaking in acid solution, the crushed particles were dried at $100{ }^{\circ} \mathrm{C}$ for $24 \mathrm{~h}$. Then, the dried crushed particles were calcined at $700{ }^{\circ} \mathrm{C}$ for $2 \mathrm{~h}$ in a furnace. Ultimately, the prepared $\mathrm{MgO}$ nanocatalyst was manually powdered. After preparation, the final product for next use was placed in a polyethylene container. The detailed characterizations of the $\mathrm{MgO}$ were conducted with field emission scanning electron microscopy (SEM; Sigma model VP-500, Zeiss), Fourier transform infrared (FTIR) spectroscopy (Spectrum Two model, PerkinElmer), X-ray diffraction (XRD; X'pert Pro model, Panalytical), and energy dispersive X-ray spectroscopy (EDX). Brunauer-Emmett-Teller (BET; Belsorp Mini model, Microtrac Bel Corp.) surface area and total pore volumes of the nano-catalyst were determined via nitrogen adsorption isotherms at $77 \mathrm{~K}$. All the experiments with the methotrexate drug were performed after catalyst confirmation. The methotrexate structural formula and its

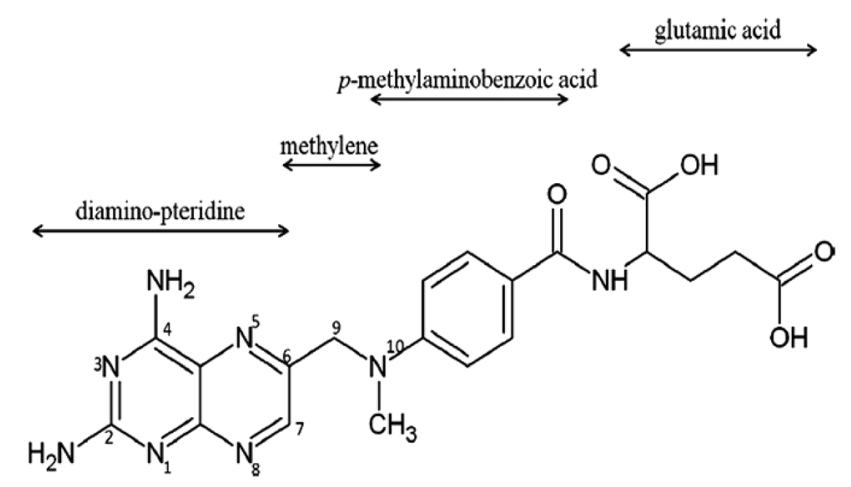

Fig. 1 The methotrexate (crystalline powder and orange-brown) structural formula and its properties. ${ }^{16}$ 


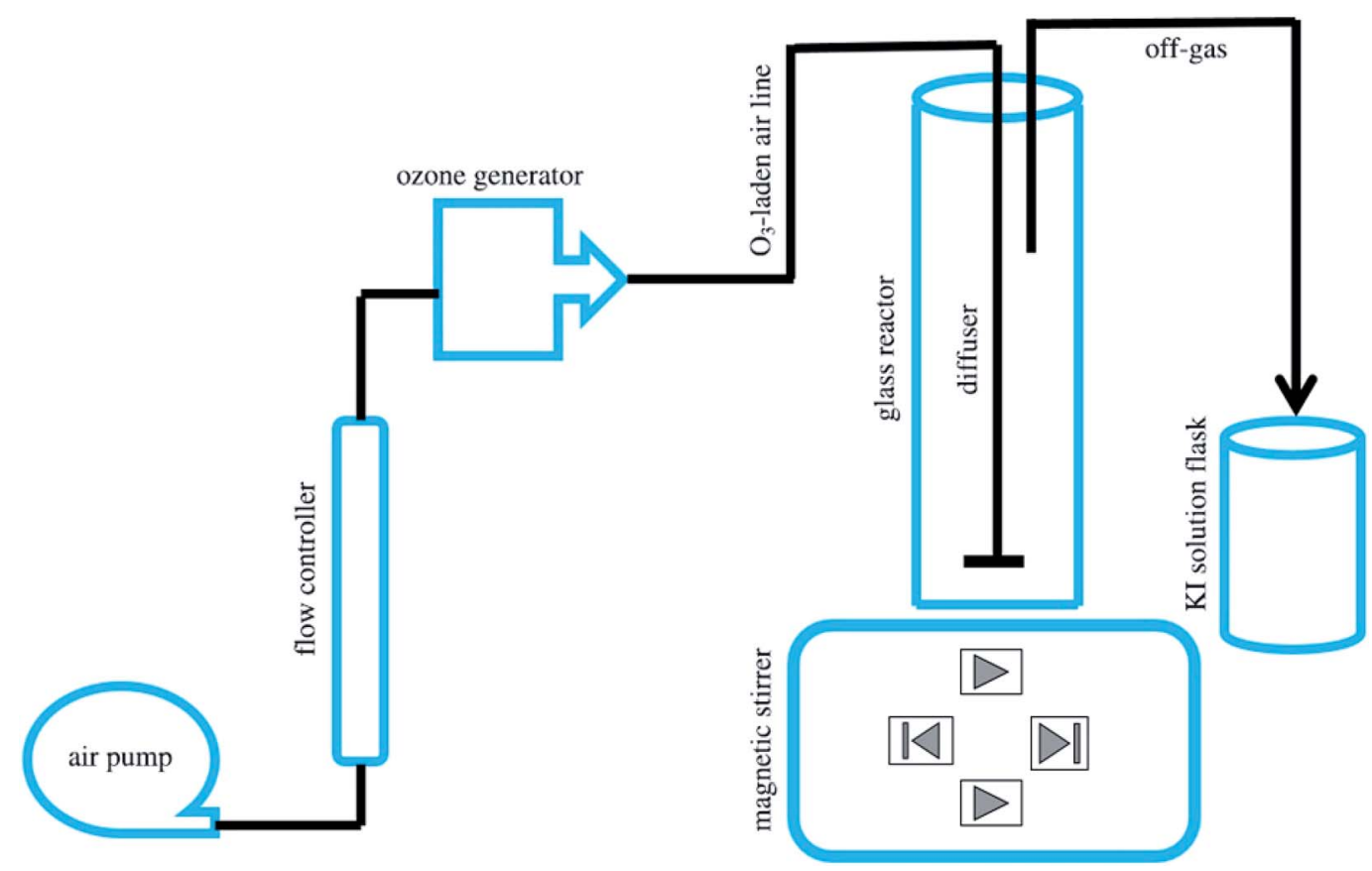

Fig. 2 A view of the pilot used.

properties are shown in Fig. 1. Its molecular formula is $\mathrm{C}_{20} \mathrm{H}_{22} \mathrm{~N}_{8} \mathrm{O}_{5}$ and its molecular weight is $454.447 \mathrm{~g} \mathrm{~mol}^{-1}$. Also, its solubility in water is $2600 \mathrm{mg} \mathrm{l}^{-1}$. All experiments were carried out in batch conditions. Fig. 2 shows a view of the pilot used. The pilot used and its components were similar to those of the Moussavi et al. study. ${ }^{28}$ Main parts of the pilot used included an (A) air pump, (B) ozone generator and (C) supply system, a flow controller, an ozonation reactor, glass reactor, magnet, diffuser, catalyst particles, ozone bubbler, magnetic stirrer, a destruction system of off-gas $\mathrm{O}_{3}$, and solution flask of potassium iodide (KI). Ozone is formed by an ozonator and it can be passed through the glass diffuser to the reactor. The reactions of SOPs and COPs were performed in a $250 \mathrm{ml}$ Pyrex glass reactor. To create fine bubbles, a magnetic stirrer was used. A stock solution of methotrexate $\left(500 \mathrm{mg} \mathrm{l}^{-1}\right)$ was prepared weekly in high-quality distilled water and stored at standard temperature $\left(4^{\circ} \mathrm{C}\right)$. The main variables considered for the effect of SOPs and COPs on target pollutant were initial methotrexate concentration ( 5 to $30 \mathrm{mg} \mathrm{l}^{-1}$ ), contact time ( 5 to $60 \mathrm{~min}$ ), solution $\mathrm{pH}$ ( 4 to 10$)$, and $\mathrm{MgO}$ dosage ( 0.1 to $0.5 \mathrm{~g}$ $\left.\mathrm{l}^{-1}\right)$. Also, the methotrexate mineralization was determined using TOC (total organic carbon). ${ }^{33}$ To determine the methotrexate concentration, high-performance liquid chromatography (HPLC) was used. An HPLC system (Shimadzu Corp., Kyoto, Japan) consisting of a quaternary pump (LC-10ATvp), UV-visible detector (SPD-M10Avp), vacuum degasser and system controller (SCL-10Avp) was used. A manual injector with a $10 \mu \mathrm{l}$ sample loop was used for loading the sample. A Class VP-LC workstation was used to acquire and process chromatographic data. An RP cyano analytical column $(150 \times$ $4.6 \mathrm{~mm}, 5 \mu \mathrm{m}$; MZ-Analysentechnik GmbH, Germany) was used. Also, the influence of a scavenger on the performance of
COPs in methotrexate oxidation was studied. tert-Butanol $\left(0.5 \mathrm{~g} \mathrm{l}^{-1}\right)$ was used as the scavenger. To study the mechanism dominating the interaction of COPs with $\mathrm{MgO}$ in methotrexate oxidation, the tert-butanol method was used. ${ }^{28}$

\section{Cell cultures}

In the present work, the effect of MTX, SOP $\left(\mathrm{O}_{3}\right)$ and COP $(\mathrm{MgO}$ $+\mathrm{O}_{3}$ ) extracts on the A549 cell line was investigated by MTT assay. Cell cultures were conducted with A549 cells derived from type II like human lung epithelial carcinoma in sterile plastic flasks. In this study, the A549 cells were purchased from the National Center for Cell Bank Science, Pasteur Institute of Iran (Tehran) (NCBI Code: C137). The flasks were maintained in lowglucose medium (DMEM) that contained $10 \mathrm{mg} \mathrm{ml}^{-1}$ of $1 \%$ penicillin/streptomycin, $10 \%$ fetal calf serum, and $200 \mathrm{mM}$ of $2 \%$ L-glutamine. Then, they were exposed to $5 \%$ atmospheric carbon dioxide at $37^{\circ} \mathrm{C}$. After maintaining the A549 cell cultures $\left(1 \times 10^{4}\right.$ cells per $\left.\mathrm{ml}\right)$ in plates for $24 \mathrm{~h}$, they were treated with MTX, SOP, and COP extracts at a concentration of $150 \mu \mathrm{l}$ for 12 h, 24 h, or 36 h. Fig. 10 shows contrast-phase microscopy images of A549 cells exposed to extracts. ${ }^{34}$

\section{Cytotoxicity assay by MTT method}

The MTT (3-(4,5-dimethylthiazol-2-yl)-2,5-diphenyl tetrazolium) assay was performed to determine the number of viable cells present. The A549 cell line was cultured in a 96-well plate, and then MTT was added to each well and incubated for $4 \mathrm{~h}$. After removing the supernatant, the dark blue formazan crystals were dissolved in DMSO. The absorbance of the suspension was measured at $570 \mathrm{~nm}$. The measured values were reported as 
a percentage of the control. ${ }^{35}$ The toxicity and viability were calculated using eqn (4) and (5), respectively:

$$
\begin{gathered}
\text { Toxicity } \%=\left(1-\frac{\text { mean OD of sample }}{\text { mean OD of control }}\right) \times 100 \\
\text { Viability } \%=100-\text { toxicity } \%
\end{gathered}
$$

\section{Results and discussion}

\section{MgO characterization}

Different experiments were performed to determine the characteristics of the synthesized MgO. The SEM image of the MgO nano-catalyst is shown in Fig. 3A. The XRD pattern of the synthesized $\mathrm{MgO}$ is presented in Fig. 3B and indicates the crystalline particles of $\mathrm{MgO}$ in the powder. The results of the synthesis of $\mathrm{MgO}$ nano-crystals are consistent with the results of other researchers. ${ }^{22,36}$ BET test results are presented in Table 1. The BET results indicated the surface area of MgO nanocatalyst was $140 \mathrm{~m}^{2} \mathrm{~g}^{-1}$. Based on the BJH plot, the size of $\mathrm{MgO}$ nano-catalyst particles was $44.5 \mathrm{~nm}$. The Debye-Scherrer equation was also used to estimate the size of $\mathrm{MgO}$ nanocrystals more accurately. ${ }^{23}$ Based on this equation, a size of $\mathrm{MgO}$ nano-crystals of $42.5 \mathrm{~nm}$ was obtained. In the Moussavi et al. study, the size of the synthesized $\mathrm{MgO}$ was in the range of $38 \mathrm{~nm}$ to $44 \mathrm{~nm}$, with an average specific surface area of 153.7 $\mathrm{m}^{2} \mathrm{~g}^{-1} \cdot{ }^{37}$ In the Kermani et al. study, the size of the synthesized $\mathrm{MgO}$ was $43 \mathrm{~nm}$, with an average specific surface area of $137 \mathrm{~m}^{2} \mathrm{~g}^{-1} \cdot{ }^{38}$ Also, an average pore volume of $\mathrm{MgO}$, based on BET, was $0.4454 \mathrm{~cm}^{3} \mathrm{~g}^{-1}$. The constituent elements of synthesized $\mathrm{MgO}$ were determined with EDX analysis, as shown in Fig. 4. The weight percent of $\mathrm{Mg}$ and $\mathrm{O}$ was $61.09 \%$ and $38.91 \%$, respectively. As seen in Fig. 4 , the prepared nanocatalyst was composed mainly of MgO. Fig. 5 shows the FTIR spectrum (4000-400 $\mathrm{cm}^{-1}$ ) of the $\mathrm{MgO}$ nano-catalyst. In this spectrum, several different peaks are seen. The $3700 \mathrm{~cm}^{-1}$ band was associated with the $\mathrm{O}-\mathrm{H}$ bonds and phenolic functional groups. ${ }^{39}$ The bands at $2000 \mathrm{~cm}^{-1}$ to $2500 \mathrm{~cm}^{-1}$ were related to $\mathrm{CO}_{2}$ from the atmosphere. Also, the range between
Table 1 Some properties of $\mathrm{MgO}$ from adsorption-desorption experiments (based on $\mathrm{N}_{2}$ ) at $77 \mathrm{~K}$

\begin{tabular}{llll}
\hline Sample & $\mathrm{SA}_{\mathrm{BET}}\left(\mathrm{m}^{2} \mathrm{~g}^{-1}\right)$ & $\begin{array}{l}\text { Total pore volume } \\
\left(\mathrm{m}^{3} \mathrm{~g}^{-1}\right)\end{array}$ & $\begin{array}{l}\text { Mean pore diameter } \\
(\mathrm{nm})\end{array}$ \\
\hline $\mathrm{MgO}$ & 140 & 0.3124 & 44.5 \\
\hline
\end{tabular}

1000 and $1500 \mathrm{~cm}^{-1}$ shows bands due to the $\mathrm{MgO}$ framework. ${ }^{11,28,39}$

\section{Influence of $\mathrm{pH}$ on the process}

The solution $\mathrm{pH}$ is an influential parameter in the degradation of organic matter during SOPs and COPs. Actually, due to the amphoteric behavior of most semiconductor oxides, the solution $\mathrm{pH}$ is one of the important parameters in these reactions. ${ }^{40}$ The solution $\mathrm{pH}$ affects the state of degradation materials, $\mathrm{O}_{3}$ decomposition, and the properties of the surface catalyst. ${ }^{41,42}$ To better consider the effect of solution $\mathrm{pH}$ on the degradation of methotrexate using a metal catalyst, its effect on SOPs and COPs was investigated. The removal efficiency of methotrexate by the combined process was considered in the $\mathrm{pH}$ range of 4 to 10 . The results of the effect of solution $\mathrm{pH}$ on the degradation of methotrexate are shown in Fig. 6. As shown in Fig. 6, the solution $\mathrm{pH}$ plays an important role in the photo-catalytic reactions. In acidic and alkaline $\mathrm{pH}$, the degradation of methotrexate showed a higher increase in the SOPs and COPs than neutral $\mathrm{pH}$. The degradation of methotrexate from the solution increased for a $\mathrm{pH}$ of 7 and reached a maximum of $87 \%$ at a $\mathrm{pH}$ near 8 , which is $23 \%$ higher than that at a $\mathrm{pH}$ of 4 . When $\mathrm{pH}$ increases to alkaline $\mathrm{pH}$, the degradation rate of $\mathrm{O}_{3}$ accelerates, resulting in the production of more reactive radicals. ${ }^{22,38}$ The main reason for increasing the degradation rate of methotrexate in acidic $\mathrm{pH}$ can be attributed to the very slow $\mathrm{O}_{3}$ degradation in such conditions and $\mathrm{O}_{3}$ is the main radical of the reaction with the pollutants which reacts selectively. In COPs with MgO nanocrystals, the degradation of methotrexate increases with increasing $\mathrm{pH}$. The main reason is that $\mathrm{O}_{3}$ acts as an electrophile agent and can attack the centers of high electron density of methotrexate. As mentioned earlier, at $\mathrm{pH}$ higher than $\mathrm{p} K_{\mathrm{a}}$, it
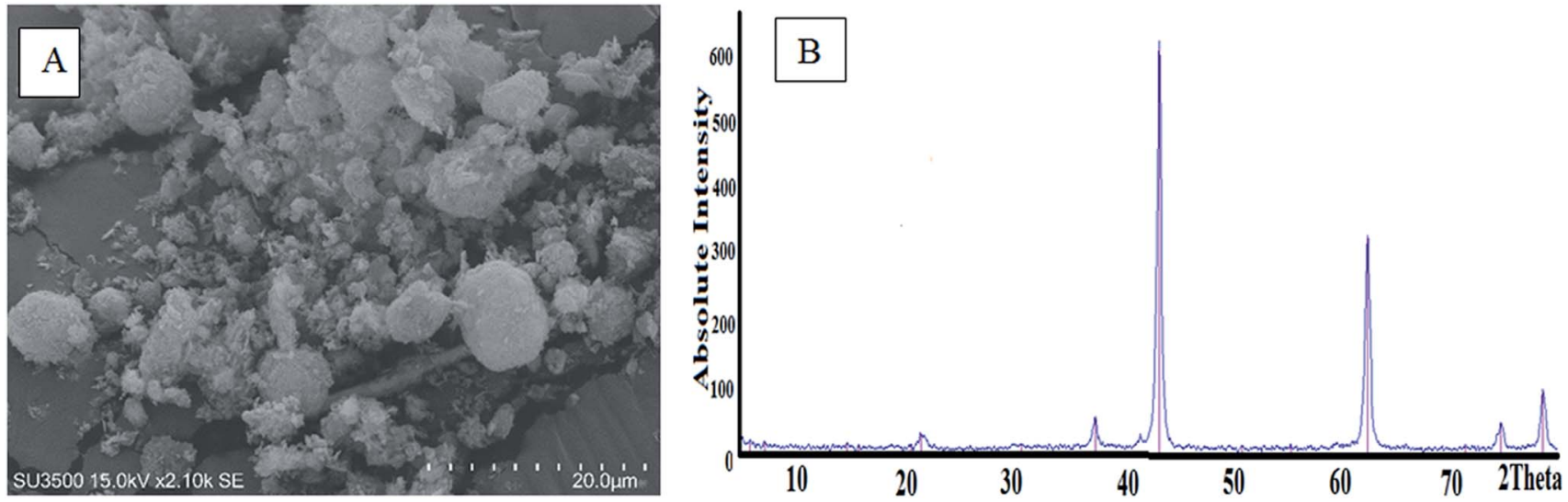

Fig. 3 SEM image (A) and XRD pattern (B) of the synthesized MgO nano-catalyst. 


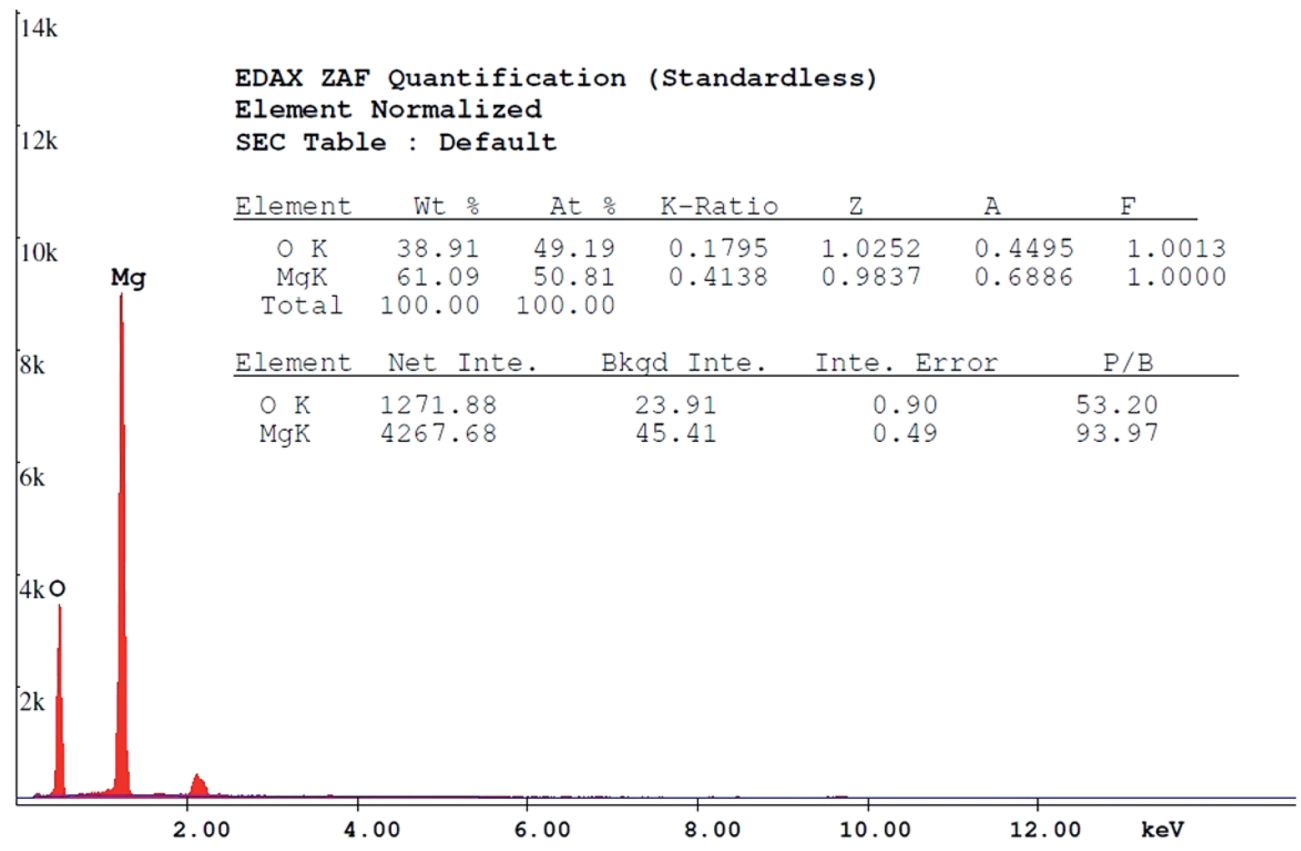

Fig. 4 EDX spectrum of the synthesized MgO nano-catalyst.

contaminates the anionic material, and thus the $\mathrm{O}_{3}$ reacts with it. ${ }^{43}$ The $\mathrm{pH}$ of zero point of charge $\left(\mathrm{pH}_{\mathrm{zpc}}\right)$ for $\mathrm{MgO}$ was obtained as nearly 10.5. Based on $\mathrm{pH}_{\mathrm{zpc}}$, the surface charges on $\mathrm{MgO}$ at $\mathrm{pH}$ higher and lower than $\mathrm{pH}_{\mathrm{zpc}}$ are negative and positive, respectively. Another reason for the increasing degradation rate of methotrexate in alkaline $\mathrm{pH}$ in COPs is the increase in the production of $\cdot \mathrm{OH}$ radicals in comparison with SOPs. Also, in fact, increasing the solution $\mathrm{pH}$ increases both the transfer of $\mathrm{O}_{3}$ gas and its degradation rate in COPs. For the study and determination of the COPs mechanism, determining the $\mathrm{pH}_{\mathrm{zpc}}$ is very important. The role of $\mathrm{pH}_{\mathrm{zpc}}$ in the performance of metal catalysts is in three ways: (1) if the solution $\mathrm{pH}$ is less than $\mathrm{pH}_{\mathrm{zpc}}$, the surface charge of the catalyst is positive, (2) if the solution $\mathrm{pH}$ is more than $\mathrm{pH}_{\mathrm{zpc}}$, the surface charge of the catalyst is negative, and (3) if the solution $\mathrm{pH}$ is equal $\mathrm{pH}_{\mathrm{zpc}}$, the surface charge of the catalyst is neutral. ${ }^{44}$ In this study, the best $\mathrm{pH}$ for the degradation of methotrexate was found to be near 8 . The findings of this study showed that the degradation rate of methotrexate was higher in alkaline conditions. In alkaline $\mathrm{pH}$, the concentration of $\cdot \mathrm{OH}$, which has a better oxidation power than $\mathrm{O}_{3}$, increased. So, it is expected that in alkaline conditions, due to the dominance of indirect oxidation, the degradation rate of methotrexate is higher than that in acidic conditions (direct oxidation). In fact, increasing the solution $\mathrm{pH}$ will increase the transfer of $\mathrm{O}_{3}$ gas and its degradation rate in the heterogeneous COPs. These reactions lead to the formation of highly reactive $\cdot \mathrm{OH}$ radicals and other radicals such as $\mathrm{OH}, \mathrm{HO}_{2}$, and $\mathrm{HO}_{3}$ which ultimately lead to an increase in the degradation rate of the pollutants. ${ }^{45}$

\section{Influence of initial methotrexate concentration, and catalyst dosage}

Of other variables that affect the degradation of methotrexate is its initial concentration. Actually, methotrexate is found in

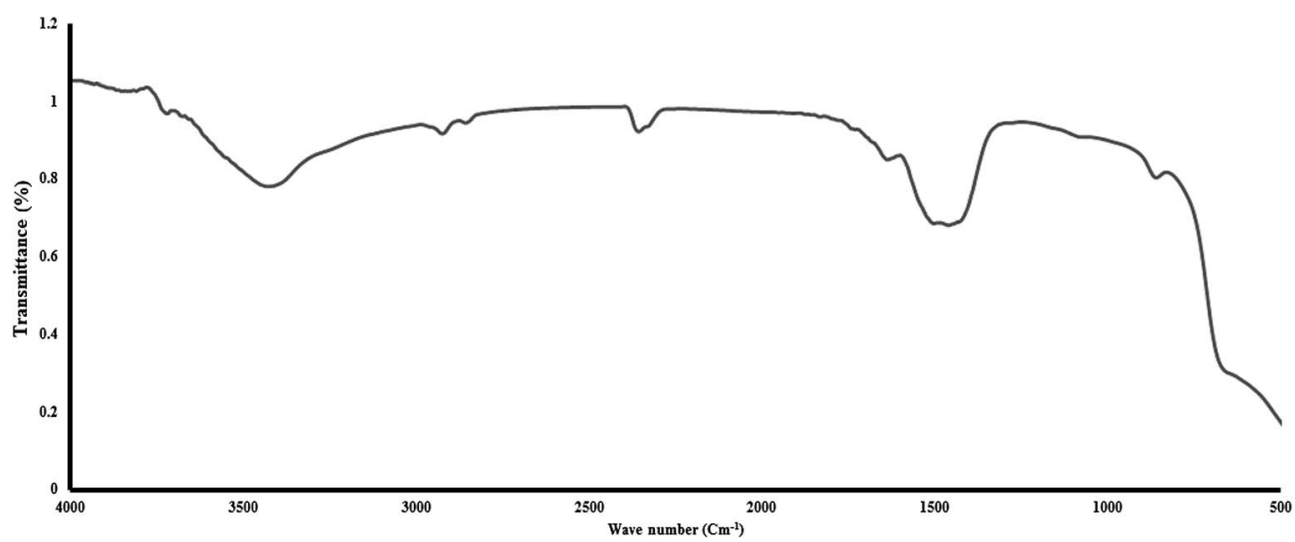

Fig. 5 FTIR spectrum of the synthesized MgO nano-catalyst. 


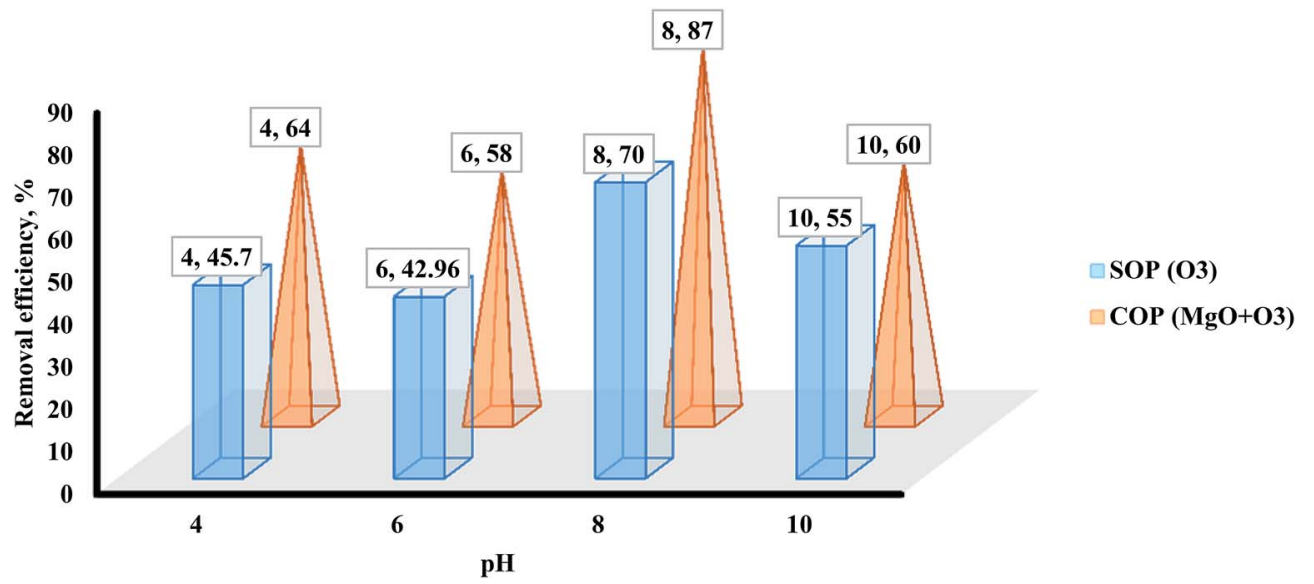

Fig. 6 The effect of the solution $\mathrm{pH}$ on methotrexate degradation by SOPs and COPs.

different concentrations in various wastewaters. Pharmaceutical wastewaters often have different concentrations of drugs. Therefore, different concentrations of methotrexate were investigated. The initial concentration of methotrexate was considered in the range of 5-30 $\mathrm{mg} \mathrm{l}^{-1}$. The effect of the initial concentration of target pollutant on the methotrexate degradation by SOPs and COPs is shown in Fig. 7. Based on Fig. 7, the degradation rate of methotrexate decreased with increasing concentration (from 5 to $30 \mathrm{mg} \mathrm{l}^{-1}$ ). By increasing the concentration, the methotrexate molecules increase in the environment, but because of the low $\cdot \mathrm{OH}$ radical production from $\mathrm{O}_{3}$ depletion, its degradation occurred more slowly at higher concentrations. As can be seen from Fig. 7, the degradation rate of methotrexate decreased with increasing concentration. The reduction in the degradation rate of methotrexate due to an increase in concentration can be attributed to the competition of the reaction with $\cdot \mathrm{OH}$ radicals at higher concentrations. ${ }^{46}$ By increasing the initial concentration, the removal efficiency decreases and there is an inverse correlation between the methotrexate concentration and the degradation rate. At higher concentrations, available sites for methotrexate adsorption are reduced which ultimately leads to a reduction in the degradation rate. Also, active sites on $\mathrm{MgO}$ are occupied by methotrexate molecules with a negative charge. One of the main reasons for the reduction in the degradation rate of methotrexate is the production of intermediates which are formed during the degradation. These intermediates can occupy active sites on the catalyst and, finally, reduce the reaction sites for methotrexate. ${ }^{25}$ One of the other variables that affect the degradation rate of methotrexate is the required catalyst $\left(\mathrm{MgO}_{3}\right)$ dosage. Actually, one of the main parameters in the continuation of the COPs is determining the required catalyst content. According to a review, catalyst dosage can increase surface area and active sites for more $\mathrm{O}_{3}$ degradation. Also, the characterization of the catalyst will play a vital role in COPs. ${ }^{47}$ To determine the optimal dose of $\mathrm{MgO}$, the COP was performed with different concentrations of nano-crystal $\left(0.1-0.5 \mathrm{~g} \mathrm{l}^{-1}\right)$. At first, by increasing the $\mathrm{MgO}$ dose, the degradation rate of methotrexate in the COP increased. In these conditions, the main reason for the increased degradation of methotrexate can be

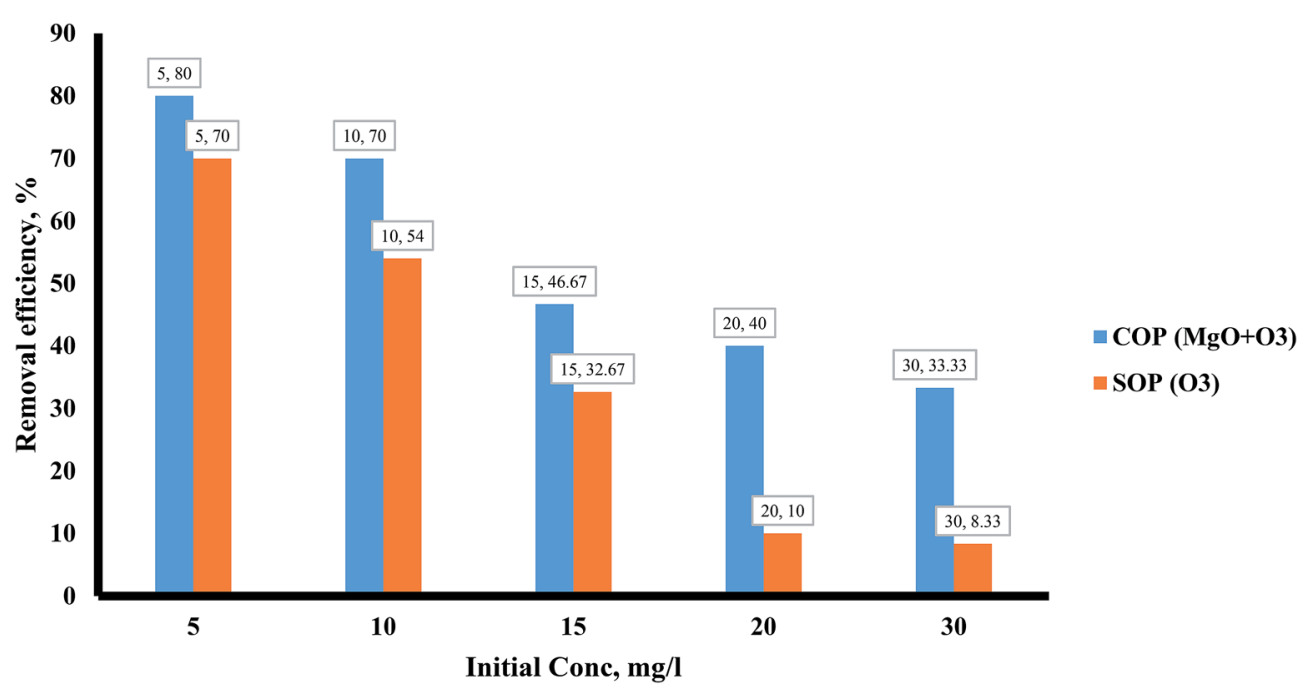

Fig. 7 The effect of initial concentration on methotrexate degradation by SOPs and COPs. 
attributed to the increasing active sites and levels on the surface of the catalyst for more $\mathrm{O}_{3}$ and drug. The maximum removal efficiency was observed at $\mathrm{MgO}$ dose of $0.4 \mathrm{~g} \mathrm{l}^{-1}$. Further increases in $\mathrm{MgO}$ dosage do not have a significant effect on the degradation of methotrexate. The optimal dose of MgO nanocrystal has been reported by Kermani et al., in the removal of metronidazole with COPs, and by Moussavi et al., in the removal of the reactive red 198 azo dye with COPs, with values of $0.25 \mathrm{~g}$ $\mathrm{l}^{-1}$ and $5 \mathrm{~g} \mathrm{l}^{-1}$, respectively. ${ }^{22,38}$ Also, the results of these studies showed that at higher doses than optimal, the amount of removal of the target pollutants is reduced. Depending on the type of pollutant, the optimum dose can also be different. The reaction mechanism of the degradation of $\mathrm{O}_{3}$ on metal oxides has been reported as follows: ${ }^{48}$

$$
\begin{gathered}
\mathrm{O}_{3}+* \Rightarrow \mathrm{O}^{*}+\mathrm{O}_{2} \\
\mathrm{O}_{3}+\mathrm{O}^{*} \Rightarrow \mathrm{O}_{2}^{*}+\mathrm{O}_{2} \\
\mathrm{O}_{2}^{*} \Rightarrow+\mathrm{O}_{2}+{ }^{*}
\end{gathered}
$$

There are various reports that the use of metal oxides as a catalyst can enhance the efficiency of SOPs for the degradation of environmental pollutants. ${ }^{\mathbf{4 9 5 0}}$ In the application of any type of catalyst in the degradation of pollutants, the adsorption process will be unavoidable. Catalytic adsorption capacity is one of the important factors that can affect the efficiency of COPs. For this, the adsorption capacity of $\mathrm{MgO}$ nano-crystal was considered. The results showed that the adsorption of methotrexate on $\mathrm{MgO}$ was very low and can be ignored. The findings of Kermani et al. on the removal of metronidazole by COPs in the presence of $\mathrm{MgO}$ nanoparticles showed that the adsorption rate of the drug was less than $1 \% .^{38}$ By increasing the contact time, the degradation rate of methotrexate in both SOPs and COPS was increased. Actually, the methotrexate degradation in COPs was faster than in SOPs. It was also observed that in a shorter time, the degradation of methotrexate in COPs was much higher than that in SOPs. These results can be attributed to the synergistic properties of COPs. In previous studies, such synergistic properties have also been observed. ${ }^{11,51,52}$ The reactions which occurred in the presence of a catalyst and lead to the synergistic properties of COPs can be expressed as follows: as the catalyst dose increases, the available surface area and active sites increase, so more $\mathrm{O}_{3}$ will be adsorbed in places. The net result of these interactions would be to increase the production of $\cdot \mathrm{OH}$ radicals and surface reactions. ${ }^{11,51}$

\section{Influence of scavenger and mineralization on the degradation of methotrexate}

One of the important problems with SOPs and COPs is the negative effects of interfering factors through radical consumption and the consequent reduction of the removal efficiency of these processes. The presence of a scavenger in SOPs and COPs prevents proper formation of $\cdot \mathrm{OH}$ radicals. In the absence of a scavenger and in usual conditions, $\mathrm{O}_{3}$ molecules can adsorb on the surface of metal oxide $(\mathrm{MgO})$ and react with $\cdot \mathrm{OH}$ on the catalyst surface. In the presence of a scavenger, because of interfering agents on the catalyst surface, $\mathrm{O}_{3}$ molecules cannot react with $\cdot \mathrm{OH}$ surface groups. Subsequent reactions, as a result, for the production of active radicals will be disrupted and the degradation rate of the pollutants will be reduced. ${ }^{47,53}$ Fig. 8 shows the effect of tert-butanol on the degradation of methotrexate in SOPs and COPs. The study findings showed that the use of tert-butanol as a scavenger reduced the degradation rate of methotrexate. Reduced removal efficiency in SOPs (single $\left.\mathrm{O}_{3}\right)$ and COPs $\left(\mathrm{O}_{3}+\mathrm{MgO}\right)$ was $32 \%$ and $31 \%$, respectively. Based on the findings of this study, it can be said that the main mechanism involved in the degradation of methotrexate is an indirect reaction with $\cdot \mathrm{OH}$ radicals. Reduction of drug degradation rate when adding tert-butanol confirms the predominance of the indirect oxidation system in the process. Other researchers have reported similar results. ${ }^{47,52}$ tert-Butanol, as a powerful scavenger, with the formation of a stronger bond with functional groups on the $\mathrm{MgO}$ surface, prevents the proper performance of the oxidation. ${ }^{54}$ In aquatic environments, the degradation rate of $\mathrm{O}_{3}$ molecules because of the presence of $\cdot \mathrm{OH}$ scavengers can considerably decrease. tertButanol is an alcohol and can function in AOPs as a scavenger; therefore, it can greatly reduce the degradation rate of methotrexate molecules. This phenomenon can be justified in that the

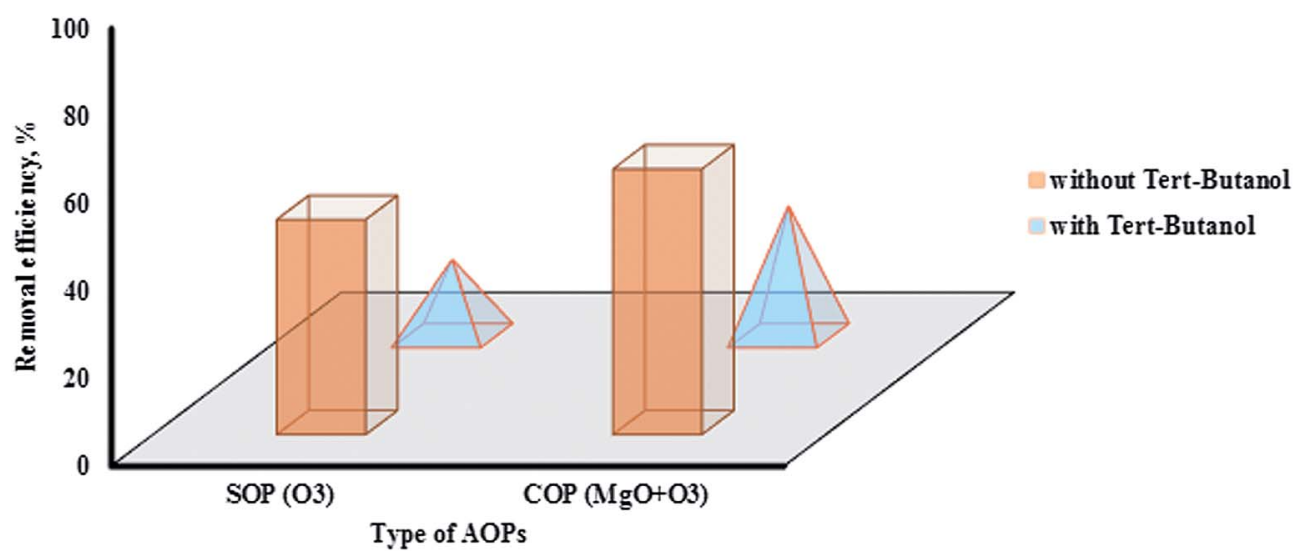

Fig. 8 The effect of tert-butanol on degradation and mineralization of methotrexate in SOPs and COPs. 
reaction rate between $\mathrm{O}_{3}$ and tert-butanol is higher than that between $\mathrm{O}_{3}$ and methotrexate molecules. It ultimately leads to a reduction in production of $\cdot \mathrm{OH}$ radicals. The reaction rate of $\mathrm{O}_{3}$ and tert-butanol and of $\mathrm{O}_{3}$ and methotrexate molecules (as a pollutant) is $5 \times 10^{8} \mathrm{~mol}$ per second and $0.3 \mathrm{~mol}$ per second, respectively. While for SOPs in the presence of oxidant agents, reduction of the effectiveness of the process will be negligible. ${ }^{52,55}$ So, it can be concluded that degradation reactions of methotrexate occurred more at the $\mathrm{MgO}$ surface. TOC measurement for the degradation of methotrexate indicates mineralization of the target pollutant in SOPs and COPs. Fig. 9 shows the effect of mineralization of methotrexate in SOP and COP based on TOC. Highest mineralization in the degradation of methotrexate was related to $\mathrm{COP}\left(\mathrm{O}_{3}+\mathrm{MgO}\right)$. The mineralization in SOP and COP was $20 \%$ and $45 \%$, respectively. Therefore, COPs in comparison with SOPs can have high power in the mineralization of environmental pollutants.

\section{Effect of reaction time and kinetics of methotrexate degradation in catalyst ozonation processes}

The results of kinetics of reactions showed that the reaction rate of SOPs increased from $0.0345 \mathrm{~min}^{-1}$ to $0.0965 \mathrm{~min}^{-1}$ for COPs. It can be concluded that the addition of $\mathrm{MgO}$ nanocrystals increased the degradation rate of methotrexate in COPs by about 2.79 times compared to SOPs. Based on the ozonation theory and the results of this study, in the COP of methotrexate in the presence of $\mathrm{MgO}$ nanocrystals, molecules of $\mathrm{O}_{3}$ and methotrexate were adsorbed in the $\mathrm{MgO}$ surface and then the pollutant was oxidized using $\mathrm{O}_{3}$. Adsorption by the $\mathrm{MgO}$ nanocrystals increased the probability of reaction between $\mathrm{O}_{3}$ molecules and methotrexate; as a result, the degradation rate of methotrexate increased. In addition to the direct reactions of methotrexate with $\mathrm{O}_{3}$ molecules, the indirect reactions of the radicals produced at the $\mathrm{MgO}$ surface and in the solution can also be involved in the mechanism of methotrexate degradation. The degradation of pollutants in the ozonation process consists of two main paths: direct (using $\mathrm{O}_{3}$ molecules) and indirect (using other radicals generated by $\mathrm{O}_{3}$ ) oxidation. The indirect oxidation system has high efficiency due to the presence of $\mathrm{OH}$ radicals and high oxidation of these radicals compared to $\mathrm{O}_{3}$ molecules. ${ }^{38}$ According to the findings of Moussavi et al. ${ }^{27}$ and Kermani et al., ${ }^{37}$ the three suggested pathways are as follows (direct and indirect reactions):

Direct reactions:

$$
\begin{aligned}
\mathrm{MgO}^{-\mathrm{O}_{3}}+\text { methotrexate } \Rightarrow \mathrm{MgO}+\mathrm{CO}_{2} & +\mathrm{H}_{2} \mathrm{O} \\
& + \text { intermediates }
\end{aligned}
$$

$$
\begin{gathered}
\mathrm{MgO}^{- \text {methotrexate }}+\mathrm{O}_{3} \Rightarrow \mathrm{MgO}+\mathrm{CO}_{2}+\mathrm{H}_{2} \mathrm{O}+\text { intermediates(10) } \\
\mathrm{O}_{3}+\text { methotrexate } \Rightarrow \mathrm{CO}_{2}+\mathrm{H}_{2} \mathrm{O}+\text { intermediates }
\end{gathered}
$$

Indirect reactions:

$$
\begin{aligned}
& \mathrm{MgO}^{-\mathrm{OH}}+\text { methotrexate } \Rightarrow \mathrm{MgO}+\mathrm{CO}_{2}+\mathrm{H}_{2} \mathrm{O} \\
&+ \text { intermediates } \\
& \mathrm{MgO}^{- \text {methotrexate }}+\cdot \mathrm{OH} \Rightarrow \mathrm{MgO}+\mathrm{CO}_{2}+\mathrm{H}_{2} \mathrm{O} \\
&+ \text { intermediates } \\
& \cdot \mathrm{OH}+\text { methotrexate } \Rightarrow \mathrm{CO}_{2}+\mathrm{H}_{2} \mathrm{O}+\text { intermediates }
\end{aligned}
$$

- $\mathrm{OH}$ radicals react with organic matter in the ozonation process due to their reactivity and oxidation potential. For determining the best kinetic model of the degradation of methotrexate, first-order reaction (FOR) and second-order reaction (SOR) were examined. Kinetic constants for degradation and mineralization of methotrexate in SOPs and COPs are shown in Table 2. Based on Table 2, the best kinetic model describing the data obtained in SOPs and COPs was FOR. The model of FOR had the highest coefficient of determination $\left(R^{2}\right.$ or $R$-square).

\section{Cytotoxicity analysis}

In this study, the effect of MTX, SOP, and COP extracts after treatment on the cell viability of A549 cells determined by MTT assay for a concentration of $150 \mu \mathrm{l}$ with different contact times

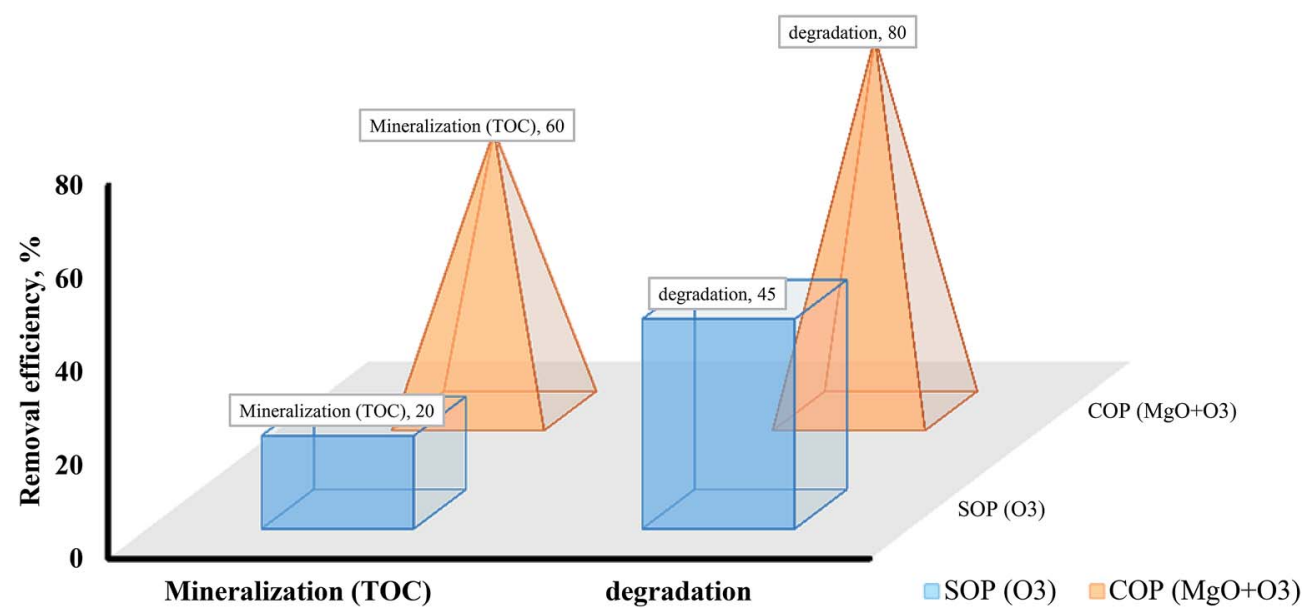

Fig. 9 The effect of mineralization of methotrexate in SOPs and COPs based on TOC. 
Table 2 Kinetic constants for degradation and mineralization of methotrexate in catalyst ozonation processes

\begin{tabular}{lll}
\hline Type of process & $\begin{array}{l}\text { First-order } \\
\text { reaction }\end{array}$ & $\begin{array}{l}\text { Second-order } \\
\text { reaction }\end{array}$ \\
\hline $\mathrm{SOP}\left(\mathrm{O}_{3}\right)$ & 0.87 & 0.76 \\
$\mathrm{COP}\left(\mathrm{MgO}+\mathrm{O}_{3}\right)$ & 0.95 & 0.85
\end{tabular}

of 12,24 , or $36 \mathrm{~h}$ was investigated. The results are shown in Fig. 10 and 11 . The cytotoxicity results are presented as the percentage decrease in viable cells with respect to negative controls. A wide range of cytotoxicity values was obtained for the three extracts (MTX, SOP, and COP) ranging from $8 \%$ to $92 \%$ for 12 h, 24 h, or 36 h. As shown in Fig. 11, all three types of extract (MTX, SOP, and COP) inhibit cell proliferation and decrease cell viability. In accordance with other studies, the cell viability for MTX extract for the different contact times significantly decreased in comparison with the control cells $\left(P_{\text {value }}<0.05\right)$. Generally, the greatest survival percentage of cells in each of the three types of extract was observed for the COP extract at an incubation time of $12 \mathrm{~h}$ (92\%), whereas the lowest was observed for the MTX extract at an incubation time of $48 \mathrm{~h}(25.6 \%)$. Statistical analysis revealed a significant difference between the MTX extract and SOP and COP samples in terms of the percentage of viable cells when in contact with A549 cell line. The findings indicated that the cytotoxicity effect strengthens with an increase of the drug concentration and contact time. ${ }^{\mathbf{1 4}}$ MTX is found to be more toxic with a viability of $25.6 \%$ and $8 \%$ for $12 \mathrm{~h}$ and $36 \mathrm{~h}$ of incubation, respectively. More toxicity, in this case, is due to the free existence and direct contact of the drug with the cells. Cytotoxicity assay done on A549 cell line revealed that the COP extract exhibited an average of $53 \%$ and $44 \%$ of cell death for $24 \mathrm{~h}$ and $36 \mathrm{~h}$ of incubation, respectively. MTX belongs to a group of drugs with high-risk side effects. It is a mutagen and a teratogen anticancer drug which belongs to the subgroup of the antimetabolites and acts by blocking enzyme activity and disrupting DNA synthesis. ${ }^{56}$ In an in vitro study on A549 cell line culture, the cytotoxicity of MTX extract and SOP and COP

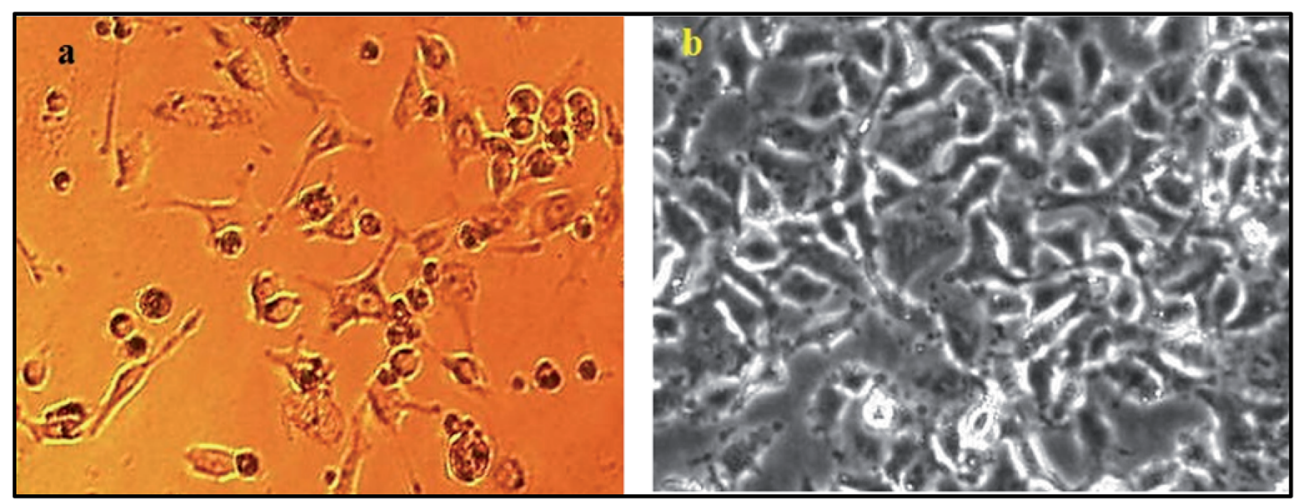

Fig. 10 Contrast phase microscopy observations of extract-exposed A549 cells. (a) Non-exposed cells. (b) A549 cells treated with MTX, SOP (O 3 ) and $\mathrm{COP}\left(\mathrm{MgO}+\mathrm{O}_{3}\right)$ extracts.

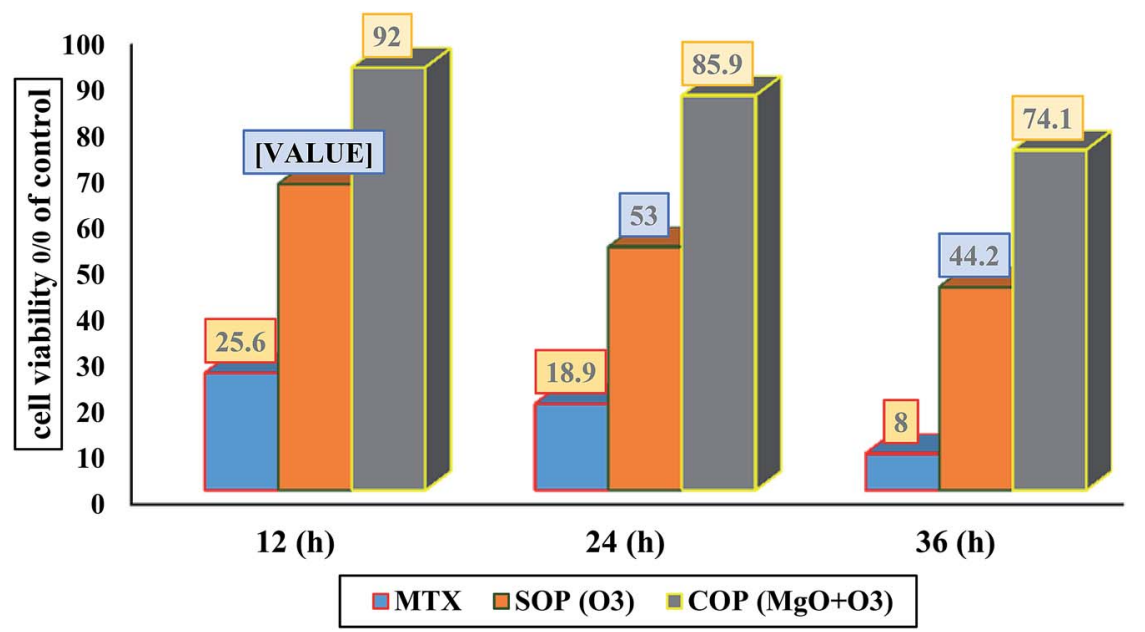

Fig. 11 Effect of exposure to MTX, SOP $\left(\mathrm{O}_{3}\right)$ and $\mathrm{COP}\left(\mathrm{MgO}+\mathrm{O}_{3}\right)$ extracts on cell viability of $\mathrm{A} 549$ cells by $\mathrm{MTT}$ assay for a concentration of $150 \mu \mathrm{l}$ with different contact times of 12, 24, or $36 \mathrm{~h}$. 
samples was investigated. The effect of these extracts and their combination on viability (MTT test) and apoptosis of the cells was assessed.

\section{Conclusions}

The present study considered the effects of SOPs and COPs on the removal and the degradation of methotrexate from aqueous solutions. The main variables considered were initial methotrexate concentration, contact time, solution $\mathrm{pH}$, and $\mathrm{MgO}$ dosage. All the experiments with the methotrexate drug were performed after catalyst confirmation. The results of the variation of $\mathrm{pH}$ showed that with increasing solution $\mathrm{pH}$, the degradation of methotrexate increased. As the results show, at all $\mathrm{pH}$ values investigated, $\mathrm{COP}$ has a better performance than SOP, and, as $\mathrm{pH}$ rises, the removal of methotrexate increased. The degradation rate of methotrexate decreased with increasing concentration. At higher concentrations, available sites for methotrexate adsorption are reduced which ultimately leads to a reduction in the degradation rate. Also, active sites on $\mathrm{MgO}$ are occupied by methotrexate molecules with a negative charge. By increasing the $\mathrm{MgO}$ dose, the degradation rate of methotrexate by COPs increased. In these conditions, the main reason for the increased degradation of methotrexate can be attributed to an increase in active sites and levels on the surface of the catalyst for more $\mathrm{O}_{3}$ and drug. It can be concluded that the addition of $\mathrm{MgO}$ nanocrystals increased the degradation rate of methotrexate in COPs by about 2.79 times compared to SOPs. In addition to the direct reactions of methotrexate with $\mathrm{O}_{3}$ molecules, the indirect reactions of the radicals produced at the $\mathrm{MgO}$ surface and in solution can also be involved in the mechanism of methotrexate degradation. High mineralization with this method can greatly reduce the environmental risks associated with the discharge of effluents containing methotrexate. In accordance with other studies, the cell viability on exposure to MTX extract for different contact times significantly decreased in comparison with the control cells $\left(P_{\text {value }}<0.05\right)$. The results of this study showed that the COP using MgO nanocrystals can be used as a pretreatment or a complete treatment for pharmaceutical wastewater or aqueous solutions containing methotrexate.

\section{Conflicts of interest}

There are no conflicts to declare.

\section{Acknowledgements}

The authors of this article acknowledge the Baqiyatallah University of Medical Sciences for providing instrumental support for this project.

\section{References}

1 B. Roig, B. Marquenet, I. Delpla, V. Bessonneau, A. Sellier, C. Leder, O. Thomas, R. Bolek and K. Kummerer, Water Res., 2014, 57, 67-75.
2 I. J. Buerge, H. Buser, T. Poiger and M. D. Müller, Environ. Sci. Technol., 2006, 40, 7242-7250.

3 A. C. Garcia, A. Broséus, R. Vincent, S. Barbeau, B. Prévost and M. Sauvé, Chemosphere, 2010, 79, 1056-1063.

4 G. Aherne, Int. J. Environ. Anal. Chem., 1985, 21, 79-88.

5 C. Catastini, J. Mullot, S. Boukari, P. Mazellier, Y. Levi, P. Cervantes and J. Ormsby, Eur. J. Water Qual., 2008, 39, 171-180.

6 S. Castiglioni, R. Bagnati, D. Calamari, R. Fanelli and E. Zuccato, J. Chromatogr. A, 2005, 1092, 206-215.

7 S. Castiglioni, R. Bagnati, R. Fanelli, F. Pomati, D. Calamari and E. Zuccato, Environ. Sci. Technol., 2006, 40, 357-363.

8 J. Yin, B. Shao, J. Zhang and K. Li, Bull. Environ. Contam. Toxicol., 2010, 84, 39.

9 G. Aherne, J. English and V. Marks, Ecotoxicol. Environ. Saf., 1985, 9, 79-83.

10 V. Matamoros, M. Hijosa and J. M. Bayona, Chemosphere, 2009, 75, 200-205.

11 A. Abdoli, R. Shokuhi, M. A. Seid and G. Asgari, Journal of Sabzevar University of Medical Sciences, 2016, 21(1), 84-94.

12 Y. Lin, S. Wu, X. Li, X. Wu, C. Yang, G. Zeng, Y. Peng, Q. Zhou and L. Lu, Appl. Catal., B, 2018, 227, 557-570.

13 W. Lai, M. Hsu and A. Lin, Water Res., 2017, 112, 157-166.

14 C. A. Lutterbeck, E. Baginska, E. Machado and K. Kümmerer, Chemosphere, 2015, 141, 290-296.

15 C. A. Somensi, E. L. Simionatto, J. B. Dalmarco, P. Gaspareto and C. M. Radetski, J. Environ. Sci. Health, Part A: Environ. Sci. Eng., 2012, 47, 1543-1550.

16 S. Barışçı, Ö. Türkay, E. Ulusoy, and A. Dimoglo, International Chemical Congress of Pacific Basin Societies, 2015.

17 Y. Lin, S. Wu, C. Yang, M. Chen and X. Li, Appl. Catal., B, 2019, 245, 71-86.

18 S. Wu, H. He, X. Li, C. Yang, G. Zeng, B. Wu, S. He and L. Lu, Chem. Eng. J., 2018, 341, 126-136.

19 S. Wu, H. Li, X. Li, H. He and C. Yang, Chem. Eng. J., 2018, 353, 533-541.

20 I. Michael, E. Hapeshi, C. Michael, A. Varela, S. Kyriakou, C. Manaia and D. Fatta-Kassinos, Water Res., 2012, 46, 5621-5634.

21 G. Moussavi, R. Khosravi and N. R. Omran, Appl. Catal., A, 2012, 445, 42-49.

22 G. Moussavi and M. Mahmoudi, Chem. Eng. J., 2009a, 152, 17.

23 J. Nawrocki and B. Kasprzyk-Hordern, Appl. Catal., B, 2010, 99, 27-42.

24 Y. Haldorai and J. Shim, Appl. Surf. Sci., 2014, 292, 447-453. 25 X. Liu, Z. Zhou, G. Jing and J. Fang, Sep. Purif. Technol., 2013, 115, 129-135.

26 F. J. Beltrán, F. J. Rivas and R. Montero-de-Espinosa, J. Chem. Technol. Biotechnol., 2003, 78, 1225-1233.

27 G. Moussavi, A. Aghapour and K. Yaghmaeian, Journal of Health and Hygiene, 2017, 8, 7-19.

28 G. Moussavi, A. Aghapour and K. Yaghmaeian, Chem. Eng. J., 2014, 249, 302-310.

29 T. Yamamoto, S. I. Kim, J. Chaichanawong, E. U. Apiluck and T. Ohmori, Appl. Catal., B, 2009, 88, 455-461. 
30 G. Moussavi and R. Alizadeh, Appl. Catal., B, 2010, 97, 160167.

31 S. Golmohammadi, M. Ahmadpour, A. Mohammadi, A. Alinejad, N. Mirzaei, M. Ghaderpoori and A. Ghaderpoori, Environ. Health Eng. Manage. J., 2016, 3, 107-113.

32 M. Moonsiri, P. Rangsunvigit and S. Chavadej, Chem. Eng. J., 2004, 97, 241-248.

33 A. D. Eaton, L. S. Clesceri, and E. W. Rice, Standard Methods for the Examination of Water and Wastewater, American Water Works Association, 2012.

34 A. Mohseni Bandpi, A. Eslami, A. Shahsavani, F. Khodagholi, A. Aliaghaei and A. Alinejad, Toxin Rev., 2017, 36, 116-124.

35 A. MohseniBandpi, A. Eslami, A. Shahsavani, F. Khodagholi and A. Alinejad, Sci. Total Environ., 2017, 593, 182-190.

36 B. Nagappa and G. Chandrappa, Microporous Mesoporous Mater., 2007, 106, 212-218.

37 G. Moussavi and M. Mahmoudi, J. Hazard. Mater., 2009b, 168, 806-812.

38 M. Kermani, F. Bahrami Asl, M. Farzadkia, A. Esrafili, A. Salahshur, H. Arfaeinia and A. Dehgani, Journal of Urmia University of Medical Sciences, 2013, 24, 839-850.

39 G. Socrates, Infrared and Raman characteristic group frequencies: tables and charts, John Wiley \& Sons, 2001.

40 M. Ghaderpoori and M. H. Dehghani, Desalin. Water Treat., 2016, 57, 15208-15212.

41 A. A. Mohammadi, A. Alinejad, B. Kamarehie, S. Javan, A. Ghaderpoury, M. Ahmadpour and M. Ghaderpoori, Int. J. Environ. Sci. Technol., 2017, 1-10.
42 Q. Sun, Y. Wang, L. Li, J. Bing, Y. Wang and H. Yan, J. Hazard. Mater., 2015, 286, 276-284.

43 M. H. Khan and J. Y. Jung, Chemosphere, 2008, 72, 690-696. 44 B. Lan, R. Huang, L. Li, H. Yan, G. Liao, X. Wang and Q. Zhang, Chem. Eng. J., 2013, 219, 346-354.

45 H. Valdes, F. Murillo, J. Manoli and C. Zaror, J. Hazard. Mater., 2008, 153, 1036-1042.

46 Y. Jiang, C. Pétrier and T. D. Waite, Ultrason. Sonochem., 2002, 9, 163-168.

47 G. Asgari, H. Almasi, J. Fardmal, F. Ghanbari, Z. Daraie and S. Akbari, J. Mazandaran Univ. Med. Sci., 2015, 24, 252-262.

48 H. C. Wang, S. H. Chang, P. C. Hung, J. F. Hwang and M. B. Chang, J. Hazard. Mater., 2009, 164, 1452-1459.

49 F. J. Beltrán, F. J. Rivas and R. Montero-de-Espinosa, Water Res., 2005, 39, 3553-3564.

50 B. Kasprzyk-Hordern, M. Ziółek and J. Nawrocki, Appl. Catal., $B, 2003,46,639-669$.

51 G. Moussavi, A. Khavanin and R. Alizadeh, J. Hazard. Mater., 2009, 171, 175-181.

52 A. Rahmani, J. Mehralipour, A. Shabanlo and S. Majidi, Journal of Qazvin University of Medical Sciences, 2015, 19, 55-64.

53 G. V. Buxton, C. L. Greenstock, W. P. Helman and A. B. Ross, J. Phys. Chem. Ref. Data, 1988, 17, 513-886.

54 G. Moussavi, A. Alahabadi, K. Yaghmaeian and M. Eskandari, Chem. Eng. J., 2013, 217, 119-128.

55 J. Staehelin and J. Hoigne, Environ. Sci. Technol., 1982, 16, 676-681.

56 R. Panonnummal and M. Sabitha, Int. J. Biol. Macromol., 2018, 110, 245-258. 